$\frac{\mathrm{DE}}{\mathrm{G}} \underset{\substack{\text { DE GRUYTER } \\ \text { OPEN }}}{\text { DOI 10.1515/ethemes-2015-0024 }}$

\title{
RESEARCH ON ELEMENTARY SCHOOL TEACHER SATISFACTION IN THE REPUBLIC OF SERBIA
}

\author{
Ivana Simić \\ University of Nis, Faculty of Economics, Republic of Serbia \\ 凶ivana.simic@eknfak.ni.ac.rs \\ Jelena Mladenović \\ PhD student, University of Nis, Faculty of Economics, Republic of Serbia \\ $\triangle$ mladenovic.jelena88@gmail.com \\ Nebojša Stojković \\ University of Nis, Faculty of Economics, Republic of Serbia \\ $\bowtie$ nebojsa.stojkovic@eknfak.ni.ac.rs \\ UDC \\ 371.12:331. \\ 101.3(497.11) \\ Original \\ scientific \\ paper \\ Received: \\ 27.02.2015 \\ Accepted: \\ 24.9.2015

\begin{abstract}
Employees' satisfaction is one of the frequently analyzed subgroups of human attitudes connected to organizational environment. The authors' aim is to study different categories of satisfaction or dissatisfaction of teachers in elementary schools in the Republic of Serbia, as a specific category of employees. The results of the research carried out have shown that teachers are dissatisfied with salaries, awards and benefits. The next category concerning the intensity of dissatisfaction is teachers' dissatisfaction with operational procedures. On the other hand, teachers are mostly satisfied with the work they are doing, with their superiors, their colleagues and system of communicating within schools.
\end{abstract} \\ Keywords: satisfaction, teachers, Republic of Serbia
}

The paper is a part of the research done within the project 179081, financed by the Ministry of Education and Science of the Republic of Serbia 


\section{Introduction}

Employees' satisfaction is one of the frequently studied subgroups of human attitudes connected to an organizational environment. This is a subgroup of people's attitudes related to the person's evaluation of various categories typical of organizational environment. Although job satisfaction can be defined in different ways (see: Feldman, Huhg, 1983; Kreitner, Kinicki, 1995; Davis, Newstrom, 1989; DuBrin, 1988), one of the most often cited definition is offered by E. A. Locke. According to this definition, job satisfaction is "comfortable or positive emotional state which is the consequence of a person's way of assessment of own business or own work experience" (Locke, 1976).

Job satisfaction level in an organization can be lower or higher. Depending on the satisfaction level, its consequences can be positive or negative. Generally, the consequences of job satisfaction can be classified in two groups: human-behavioral and economic consequences. Human-behavioral consequences are those which have a positive or negative influence on psychophysical state of an employee, as well as on the detection of various desirable or undesirable forms of employees ' behavior. Although economic consequences of job satisfaction are inseparable from human-behavioral consequences, this group of consequences is mainly related to the job satisfaction influence on quality of products and services, on employee productivity, and overall organizational performance (Simić, Stojković, 2014, 166).

Job satisfaction in an organization, its level and possible consequences (positive or negative) of this phenomenon depend on the nature of numerous factors by which it can be influenced. In general, employee satisfaction factors can be classified in three groups: individual or intrapersonal satisfaction factors, organizational factors and external satisfaction factors (Simić, Stojković, 2014, 167). Individual or intrapersonal job satisfaction factors involve various variables typical of a person as an individual (i.e. the nature of a human personality, relevant biographical characteristics, personal abilities, individual expectations, person's life satisfaction level and so on). Organizational satisfaction factors include various organizational variables which can affect employee satisfaction level (i.e. organizational structure, management style, work conditions, the nature of work which is done in an organization, interpersonal relationships, interaction of employees and so on). External satisfaction factors are those which are located outside the organization and can affect employee satisfaction, because of their connection with the organization. This is a heterogeneous group of factors which originate from different sectors (economic, social, technical and technological, legal and political, international) within the external organizational environment (Simić, Stojković, 2014, 171). 


\section{Teachers as a Specific Category of Employees}

Schools are forms of organization which have function rules similar to most other organizations (Simić, 2010, 7). The same specificities in functioning of schools are the consequence of some specific school attributes as well as specificities of the environment within which schools are functioning. In this context we can conclude that not only different organizational categories within a school can be analyzed, but also same categories can have their specific manifestation form into the school environment. That is the case with job satisfaction.

During the last few decades, there has been an increased interest of theorists and practitioners in the problem of job satisfaction of school employees (see detailed in: Bishay, 1996,147-154; Dinham, Scott, 1998, 362-378; Evans, 1998; Sharma, 2006, 349-363; Klassen, Usher, Bong, 2010, 464-486). This interest is caused, mostly, by the consequences of school employees' increased dissatisfaction. Although the results of some studies (Van den Berg, 2002, 577625) show that it is possible to talk about some universal factors which affect school employees' satisfaction level (i.e. positive relations among colleagues, promotion possibilities and so on), there are also researches (Dinham, Scott, 2000, 379-396) which confirm a more important role of the concrete environment within which a school is working. In other words, research of employees' satisfaction level in elementary schools in concrete national, economic, social, cultural and political environment, gives us the possibilities for identifying some characteristics of this environment.

The main goal of the authors of this articles is analyzing different categories of elementary school teachers' satisfaction or dissatisfaction in the Republic of Serbia.

\section{Method}

\subsection{The Sample and Procedure}

The study of teachers' satisfaction level in the Republic of Serbia included 185 teachers- examinees in nine elementary schools from the territory of Nis, Vranje and Leskovac. The sample involves teachers who teach pupils from the fifth to eighth class. The research was realized with the previous approval of schools' directors, as well as the approval of the examined teachers.

The research was realized during March of the 2013/2014 school year by the authors of this paper. Surveys were given to teachers at the beginning of the shift, with the explanation of the purpose and aim of the research, as well as with a guarantee of the anonymity. Examinees were collected at the end of the shift. The analysis included $185(80,4 \%)$ examinees out of 230 . The rest of 
examinees (45 or 19,6\%) were not included in the analysis because their questionnaires were not returned to the examiner (12 or $0,5 \%)$ or were not completed and therefore practically unusable.

In the research $125(67,57 \%)$ out of the total number of examinees $(\mathrm{N}=185)$ were male persons, and $60(32,43 \%)$ were female. When it comes to the age structure, examinees were ranked by categories, with an average age of 37 in the sample. Within the educational structure, the dominant number of examinees $(85,95 \%)$ had VII level of qualification (high professional qualification/basic four-year studies). $11,35 \%$ of examinees had finished VII/1 level of qualification (specialization/master), while 2,7\% of examinees had finished $\mathrm{VII} / 2$ level of qualification (magisterium). According to the length of service, the greater number of examinees $(62$ or $33,51 \%)$ had years of service in the range of 16-25 years. There was a smaller number of examinees with the length of service in the range of $6-15$ years ( 55 or $29,73 \%$ ). The total 41 examined $(22,16 \%)$ had years of service 26 years and more, while 27 examinees $(14,60 \%)$ had years of service up to 5 years. General data on examinees are shown in Table 1.

Table 1 General Data

\begin{tabular}{|c|c|c|c|}
\hline & & $\mathrm{N}$ & $\%$ \\
\hline \multicolumn{4}{|l|}{ GENDER } \\
\hline & MALE & 125 & 67,57 \\
\hline & FEMALE & 60 & 32,43 \\
\hline \multicolumn{4}{|l|}{ AGE } \\
\hline & UP TO 30 YEARS & 25 & 13,51 \\
\hline & $31-40$ & 45 & 24,32 \\
\hline & $41-50$ & 62 & 33,51 \\
\hline & $51-60$ & 44 & 23,78 \\
\hline & 61 AND MORE & 9 & 4,87 \\
\hline \multicolumn{4}{|c|}{ LENGTH OF WORK } \\
\hline \multirow[t]{4}{*}{ EXPERIENCE } & UP TO 5 YEARS & 27 & 14,60 \\
\hline & $6-15$ & 55 & 29,73 \\
\hline & $16-25$ & 62 & 33,51 \\
\hline & 26 AND MORE & 41 & 22,16 \\
\hline \multicolumn{4}{|c|}{ LEVEL OF QUALIFICATION } \\
\hline & VII LEVEL & 159 & 85,95 \\
\hline & VII/1 LEVEL & 21 & 11,35 \\
\hline & VII/2 LEVEL & 5 & 2,70 \\
\hline
\end{tabular}

\subsection{Instruments}

We have used questionnaires as instruments for collecting data in that research. One of questionnaires served for getting general data on respondents (they were showed in Table 1). This questionnaire involves questions about gender, age 
and educational structure, as well as questions about the length of work experience spent working as a teacher. Job Satisfaction Survey (JSS) is used as an instrument for collecting data on the teachers' satisfaction level in organization (Spector, 1985, 698). It is a questionnaire which involves 36 questions which are grouped in 9 categories (satisfaction with salary, satisfaction with promotion opportunities, satisfaction with superiors, satisfaction with benefits, satisfaction with awards, satisfaction with operational procedures, satisfaction with colleagues, satisfaction with the job itself and satisfaction with communication). Each category contains 4 items. Some items are formulated as a positive, while other items are formulated as a negative. Positively formulated items with mean values above 3 reflect the state of satisfaction. Positively formulated items with mean values below 3 reflect the state of dissatisfaction. The meaning of negatively formulated items is inverse. The adapted version of that questionnaire has been used for our research. That version uses Likert five-point scale which ranks answers from "strongly disagree" (1) to "strongly agree" (5).

For obtaining results, descriptive statistics as well as mean and standard deviation have been used. For data processing we have used statistical software SPSS 17.0.

\section{Results}

Obtained results on the basis of JSS questionnaires were sorted by categories of satisfaction and shown in 2, 3, 4, 5, 6, 7, 8, 9 and 10.

Teachers' satisfaction with salary were analyzed on the basis of 4 items: I consider myself correctly paid for the work I do (A1); Salary raises are too low and rare in this organization (A1); Judging by how much I am paid, I consider myself appreciated in this organization (A3); I am satisfied with opportunities for increasing personal earnings in this organization (A4). The results obtained on the basis of research categories of teachers' satisfaction with salary in elementary schools are shown in Table 2.

Table 2 Teachers' Satisfaction with Salary

\begin{tabular}{ccccc}
\hline ITEM & $\begin{array}{c}\text { DIRECTION OF } \\
\text { ITEM (+/-) }\end{array}$ & $\mathrm{M}$ & SD & DEVIATION \\
\hline A1 & + & 2.39 & 1.09 & -0.61 \\
A2 & - & 4.21 & 1.04 & 1.21 \\
A3 & + & 2.28 & 1.06 & -0.72 \\
A4 & + & 2.21 & 1.05 & -0.79 \\
\hline
\end{tabular}


Teachers' satisfaction with promotion opportunities was examined on the basis of the following items: there is a small number of promotion opportunities in my business (B1); Employees who do their job well have an opportunity for promotion (B2); Employees in this organization have the same level of opportunities for promotion as in other organizations (B3); I am satisfied with the promotion opportunities which I have in this organization (B4).The results gained on the basis of the examined teacher satisfaction in elementary schools with promotion opportunities, are shown in Table 3.

Table 3 Teachers' Satisfaction with Promotion Opportunities

\begin{tabular}{ccccc}
\hline ITEM & $\begin{array}{c}\text { DIRECTION OF } \\
\text { ITEM (+/-) }\end{array}$ & $M$ & SD & DEVIATION \\
\hline B1 & - & 3.17 & 1.06 & 0.17 \\
B2 & + & 3.10 & 1.24 & 0.10 \\
B3 & + & 2.44 & 1.08 & -0.56 \\
B4 & + & 2.86 & 1.07 & -0.14 \\
\hline
\end{tabular}

The category of teachers' satisfaction with superiors was examined on the basis of the following 4 items: My superior is competent for the work he/she is doing (C1); My superior is not fair to me (C2); My superior does not show interest in his/her followers' feelings (C3); I appreciate my superior (C4). Results gained on the basis of examination of teachers' satisfaction with superiors are shown in Table 4.

Table 4 Teachers' Satisfaction with Superiors

\begin{tabular}{ccccc}
\hline ITEM & $\begin{array}{c}\text { DIRECTION OF } \\
\text { ITEM (+/-) }\end{array}$ & $M$ & SD & DEVIATION \\
\hline C1 & + & 3.67 & 1.11 & 0.67 \\
C2 & - & 2.19 & 1.15 & -0.81 \\
C3 & - & 2.60 & 1.13 & -0.40 \\
C4 & + & 4.01 & 0.96 & 1.01 \\
\hline
\end{tabular}

The category of teachers' satisfaction with benefits included the following items: I am not satisfied with the benefits I have in this organization (D1); Benefits we have in this organizations are similar to benefits of employees in the majority of other organizations (D2); Benefits Packages of employees in this organizations are equal for everybody (D3); There is something we could use as a benefit in our organization, and we do not use (D4); The results gained on the basis of the examination of teachers' satisfaction with benefits are shown in Table 5. 
Table 5 Teachers' Satisfaction with Benefits

\begin{tabular}{ccccc}
\hline ITEM & $\begin{array}{c}\text { DIRECTION OF } \\
\text { ITEM (+/-) }\end{array}$ & $M$ & SD & DEVIATION \\
\hline D1 & - & 3.19 & 1.03 & 0.19 \\
D2 & + & 2.59 & 1.13 & -0.41 \\
D3 & + & 2.85 & 1.11 & -0.15 \\
D4 & - & 3.14 & 1.00 & 0.14 \\
\hline
\end{tabular}

Teachers' satisfaction with the awards was examined by the means of the following items: When I work well, I get acknowledgment which I deserve (E1); The work I do in the organization is not valued appropriately (E2); Awards for employees in this organization are modest (E3); My efforts in this organization are not awarded appropriately (E4). The results gained on the basis of the examination of teachers' satisfaction with awards are shown in Table 6.

Table 6 Teachers' Satisfaction with Awards

\begin{tabular}{ccccc}
\hline ITEM & $\begin{array}{c}\text { DIRECTION OF } \\
\text { ITEM (+/-) }\end{array}$ & $M$ & SD & DEVIATION \\
\hline E1 & + & 2.84 & 1.11 & -0.16 \\
E2 & - & 3.31 & 1.12 & 0.31 \\
E3 & - & 3.74 & 1.00 & 0.74 \\
E4 & - & 3.41 & 1.04 & 0.41 \\
\hline
\end{tabular}

The category of teachers' satisfaction with operational procedures included the following items: Numerous rules and procedures in this organization contribute to difficulty achieving high-quality performance (F1); My efforts directed towards high-quality performance are rarely blocked by bureaucratic procedures (F2); I must do a lot at work (F3); I am confronted with a lot of paperwork during my work (F4). The results gained on the basis of the examination of teachers' satisfaction with operational procedures are shown in Table 7.

Table 7 Teachers' Satisfaction with Operational Procedures

\begin{tabular}{ccccc}
\hline ITEM & $\begin{array}{c}\text { DIRECTION OF } \\
\text { ITEM (+/-) }\end{array}$ & $M$ & SD & DEVIATION \\
\hline F1 & - & 3.09 & 1.14 & 0.09 \\
F2 & + & 3.16 & 1.03 & 0.16 \\
F3 & - & 3.50 & 1.00 & 0.50 \\
F4 & - & 3.91 & 1.07 & 0.91 \\
\hline
\end{tabular}


Teachers' satisfaction with colleagues was analyzed on the basis of the following items: I love people with who I work (G1); I must do more at work because of the incompetence of my colleagues (G2); I feel good in the company of my colleagues (G3); There are a lot of debates and rivalry among colleagues (G4). The results gained on the basis of the examination of teachers' satisfaction with operational procedures are shown in Table 8.

Table 8 Teachers' Satisfaction with Colleagues

\begin{tabular}{ccccc}
\hline ITEM & $\begin{array}{c}\text { DIRECTION OF } \\
\text { ITEM (+/-) }\end{array}$ & $M$ & SD & DEVIATION \\
\hline G1 & + & 4.06 & 0.74 & 1.06 \\
G2 & - & 2.32 & 1.02 & -0.68 \\
G3 & + & 4.04 & 0.82 & 1.04 \\
G4 & - & 3.18 & 1.10 & 0.18 \\
\hline
\end{tabular}

Teachers' satisfaction with the job itself is analyzed on the basis of the following items: I think sometimes that my work is meaningless (H1); I enjoy doing my work (H2); I am proud because of the work I am doing (H3); My work is pleasant $(\mathrm{H} 4)$. The results of the research within this category of teacher satisfaction are shown in Table 9.

Table 9 Teachers' Satisfaction with Job Itself

\begin{tabular}{ccccc}
\hline ITEM & $\begin{array}{c}\text { DIRECTION OF } \\
\text { ITEM (+/-) }\end{array}$ & $\mathrm{M}$ & SD & DEVIATION \\
\hline $\mathrm{H} 1$ & - & 2.20 & 1.15 & -0.80 \\
$\mathrm{H} 2$ & + & 4.29 & 0.73 & 1.29 \\
$\mathrm{H} 3$ & + & 4.23 & 0.81 & 1.23 \\
$\mathrm{H} 4$ & + & 4.03 & 0.93 & 1.03 \\
\hline
\end{tabular}

Teachers' satisfaction with communication within the organization was examined on the basis of the following items: There is good communication in this organization (I1); This organization's aims are not totally clear to me (I2); I often have a feeling that I do not know what is happening in this organization (I3); Employees often do not understand tasks in this organization (I4). The results gained by the research category of teacher satisfaction with communication in elementary schools are shown in Table 10. 
Table 10 Teachers' Satisfaction with Communication

\begin{tabular}{ccccc}
\hline ITEM & $\begin{array}{c}\text { DIRECTION OF } \\
\text { ITEM (+/-) }\end{array}$ & $M$ & SD & DEVIATION \\
\hline I1 & + & 3.44 & 1.02 & 0.44 \\
12 & - & 2.25 & 1.00 & -0.75 \\
I3 & - & 2.70 & 1.14 & -0.30 \\
I4 & - & 2.60 & 1.08 & -0.40 \\
\hline
\end{tabular}

An overview of the positive and negative items mentioned above, referring to teachers' satisfaction or dissatisfaction shown in the survey is presented in Table 11.

Table 11 Tabular Overview of Satisfaction and Dissatisfaction Items

\begin{tabular}{|c|c|c|c|}
\hline \multicolumn{2}{|c|}{ POSITIVE ITEMS } & \multicolumn{2}{|c|}{ NEGATIVE ITEMS } \\
\hline SATISFACTION ITEMS & DISSATISFACTION ITEMS & DISSATISFACTION ITEMS & SATISFACTION ITEMS \\
\hline & A1 $(-0.61)$ & A2 (1.21) & \\
\hline & A3 $(-0.72)$ & & \\
\hline & A4 $(-0.79)$ & & \\
\hline \multirow[t]{2}{*}{ B2 $(0.10)$} & B3 $(-0.56)$ & B1 $(0.17)$ & \\
\hline & B4 $(-0.14)$ & & \\
\hline C1 $(0.67)$ & & & C2 (-0.81) \\
\hline \multirow[t]{6}{*}{ C4 (1.01) } & & & C3 $(-0.40)$ \\
\hline & D2 $(-0.41)$ & D1 (0.19) & \\
\hline & D3 $(-0.15)$ & D4 (0.14) & \\
\hline & E1 $(-0.16)$ & E2 $(0.31)$ & \\
\hline & & E3 $(0.74)$ & \\
\hline & & E4 (0.41) & \\
\hline \multirow[t]{3}{*}{ F2 (0.16) } & & F1 (0.09) & \\
\hline & & F3 $(0.50)$ & \\
\hline & & F4 (0.91) & \\
\hline G1 (1.06) & & G4 (0.18) & G2 $(-0.68)$ \\
\hline G3 $(1.04)$ & & & \\
\hline H2 (1.29) & & & H1 $(-0.80)$ \\
\hline \multicolumn{4}{|l|}{ H3 (1.23) } \\
\hline \multicolumn{4}{|l|}{ H4 (1.03) } \\
\hline \multirow[t]{3}{*}{ I1 (0.44) } & & & $12(-0.75)$ \\
\hline & & & $13(-0.30)$ \\
\hline & & & $4(-0.40)$ \\
\hline
\end{tabular}


Grouping of the satisfaction and dissatisfaction items, with an emphasis on their levels (of satisfaction/dissatisfaction), is shown in Table 12.

Table 12 Grouping of Satisfaction Items and Dissatisfaction Items

\begin{tabular}{|c|c|}
\hline SATISFACTION ITEMS & DISSATISFACTION ITEMS \\
\hline $\begin{array}{l}\text { B2 (0.10) } \\
\text { C1 (0.67) } \\
\text { C2 (-0.81) } \\
\text { C3 (-0.40) } \\
\text { C4 (1.01) } \\
\\
\\
\\
\\
\\
\\
\\
\text { F2 (0.16) } \\
\\
\text { G1 (1.06) } \\
\text { G2 (-0.68) } \\
\text { G3 (1.04) } \\
\text { H1 (-0.80) } \\
\text { H2 (1.29) } \\
\text { H3 (1.23) } \\
\text { H4 (1.03) } \\
\text { I1 (0.44) } \\
\text { I2 (-0.75) } \\
\text { I3 (-0.30) } \\
\text { I4 (-0.40) }\end{array}$ & $\begin{array}{l}\text { A1 }(-0.61) \\
\text { A2 (1.21) } \\
\text { A3 }(-0.72) \\
\text { A4 }(-0.79) \\
\text { B1 (0.17) } \\
\text { B3 (-0.56) } \\
\text { B4 }(-0.14) \\
\\
\\
\text { D1 }(0.19) \\
\text { D2 }(-0.41) \\
\text { D3 }(-0.15) \\
\text { D4 (0.14) } \\
\text { E1 (-0.16) } \\
\text { E2 (0.31) } \\
\text { E3 (0.74) } \\
\text { E4 (0.41) } \\
\text { F1 (0.09) } \\
\text { F3 (0.50) } \\
\text { F4 (0.91) } \\
\text { G4 (0.18) }\end{array}$ \\
\hline
\end{tabular}




\section{Discussion}

The category of teachers' satisfaction with their salaries (Table 2) in this questionnaire refers to so called direct salary, or what employees receive in cash as a basic salary, as a possibility for increasing the basic salary and objectively increasing of basic salary (Bogićević Milikić. 2014, 268). This is a part of the salary which employees in the education system in the Republic of Serbia receive from the budget. The data presented in Table 2 show that teachers employed in elementary schools in the Republic of Serbia are in general dissatisfied with their salaries. The mean for the first item ("I consider myself correctly paid for the work I do") from this category of teachers' satisfaction is 2.39 (SD 1.09) and shows that the majority of the examinees(65,95\%),disagre" or "strongly disagree" with the statement that they are paid adequately for the work they do. Due to the fact that direct salaries include appropriate salary raises for employees, one of the items from this category of teacher satisfaction referred to their satisfaction with salary raises as well as with the frequency of those raises ("Salary raises are too low and rare in this organization"). The mean of this item is 4.21 (SD 1.04) and it shows that the majority of examinees $(82.7 \%)$ "agree" or "strongly agrees" with the statement that salary raises in their organizations are too low and rare. One more item from the category of teachers' satisfaction with salary was "Judging by how much I am paid, I consider myself appreciated in this organization”. This item was involved in the analysis although it is more adequate for the research of employees' satisfaction in companies than for research of employees' satisfaction in schools, where salaries are financed from the budget and where all employees with the same level of professional qualification have equal salaries. The mean of this item is 2.28 (SD 1.06) and it shows that the majority of examinees disagree with a statement which is included in the mentioned item. The specificity of school, as an organization in which this research was carried out, resulted in the fact that the majority of examinees $(35.68 \%)$ had a neutral answer about this item. On the one hand, teachers are dissatisfied with their salaries, but on the other, they know that their salaries are not smaller (neither bigger) in comparison to the salaries of their colleagues. $32.43 \%$ of examinees have evaluated internal justice with "I agree". The fact that the biggest percent (68.11\%) of answers within this item has included categories "neutral" and "agree", has resulted in the mean of this item of 3.28 (SD 1.06). The specificity of a school as an organization also has had an influence on the nature of examinees' answers for the last item ("I am satisfied with the opportunities for increasing personal earnings in this organization") within the category of teachers' satisfaction with salary. Due to the fact that teachers in elementary schools do not have an opportunity for increasing their personal salaries by some additional activities, it is understandable that $68.03 \%$ of examinees are not 
satisfied with the opportunities for increasing personal salaries in school. The mean of this item is 2.21 (SD 1.05).

Teachers' satisfaction with promotion opportunities (Table 3) is the next category for analyzing the level of teachers' satisfaction. Opportunities for employees' promotion cover available chances for taking higher hierarchical positions within an organization. That means not only a higher level of responsibility but also a higher salary, which is based on better employees' results. The specificity of a school as an organization where the research has been carried out has had an influence on the nature of the results given. For example, within the first and the second item of this satisfaction category ("There is a small number of promotion opportunities in my business" and "Employees who do their job well have an opportunity for promotion") examinees' answers were too heterogeneous and the mean for the first item had a value 3.17 (SD 1.06) while the mean for the second item was 3.10 (SD 1.24). Although answers "agree" and "strongly agree" had a minimum share within both items, there were a lot answers with other values of the item. This kind of answers is the consequence of the fact that teachers in elementary schools for students from the fifth to eighth class do not have possibilities for getting higher hierarchical position which is better paid, even if they have possibilities for professional specialization. Therefore, perception of teachers in elementary schools in the Republic of Serbia about smaller chances for promotion in comparison with employees in some other organizations is logical. As a matter of fact, the third item within this category "Employees in this organization have the same level opportunities for promotion as in other organizations" has the mean of 2.44 (SD 1.08), while the fourth item "I am satisfied with promotion opportunities which I have in this organization" has the mean of 2.86 (SD 1.07). Both items reveal the answers "strongly disagree" and "disagree" were chosen most frequently.

From the organizational point of view, school directors and, possibly, directors' assistants are directly superior to teachers in elementary schools. In general, category of teachers' satisfaction with superiors (Table 4) could indicate a positive turn. The reason for that is the fact that majority of examined teachers $(64.86 \%)$ think that their superiors are competent for the work they do (the mean of the first item "My superior is competent for work he/she is doing" is 3.67 with a standard deviation of 1.11). Examined teachers also think that their superiors are fair to them (the second item "My superior is not fair to me" has the mean of 2.19 , which means that the majority of examinees, $72.97 \%$, had answers "strongly disagree" and "disagree" for this item). The third item within this category of teachers' satisfaction ("My superior does not show interest for his/her followers' feelings") reflects their perception of their superiors' emotional intelligence. The mean of this item is 2.60 (SD 1.13) and reflects the attitude of the majority of teachers (52.98\%) that their superiors show an 
interest in employees' feelings. The positive sign of this satisfaction category is the result of the fourth item ("I appreciate my superior"), too. The mean of this item is 4.01 (SD 0.96) and it is the result of the fact that $76.75 \%$ of examinees had answers "strongly agree" or "agree" with the statement in this item.

Although there is a clear difference between benefits and privilege ${ }^{2}$ in theory, there is also an impression that the practice does not recognize that difference. The first item within category teachers' satisfaction with benefits ("I am not satisfied with benefits I have in this organization") reflects examinees' opinion in connection with the category as a whole (Table 5). The mean for that item is 3.19 (SD 1.03) and this is a consequence of the fact that the majority of examinees $(43.24 \%)$ had a neutral answer, "agree" and "strongly agree". It means that $21.63 \%$ of the examinees were satisfied with the benefits in their organization. Examined teachers also think that their benefits are different from benefits of employees in other organizations. The mean of the second item within this satisfaction category ("Benefits we have in these organizations are similar to benefits of employees in the majority of other organizations") is 2.59 and it shows the majority (51.35\%) answers "strongly disagree" and "disagree". There is an interesting fact that the examined teachers think that benefits packages in their schools are not the same for everyone. The third item "Benefits Packages of employees in this organizations are equal for everybody" has the mean of 2.85 (SD 1.11) and it shows that a great number of examinees $(39.46 \%)$ do not agree with this statement, while $30.27 \%$ of examinees have a neutral attitude on this item. The last item gained the greatest number (38.38) of neutral answers ("There is something what we could use as a benefit in our organization, and we do not use"), while $37.3 \%$ of examinees "agree" or "strongly agree" with that statement. The mean of this item is 3.14 (SD 1.00) and it reflects the teachers' opinion that the benefit system in schools could be promoted.

Awards include different monetary and non-monetary granting for employees on a different basis (i.e. reaching better results in comparison to other employees, distinctly endeavoring and so on).The specificity of school as an organization which is financed by the budget leaves small chances for teacher promotion. On the other hand, the state does not have mechanisms for ensuring added teacher stimulation on the basis of special rewarding. As a result of that, a great percent of the examined teachers showed dissatisfaction for all four items within the satisfaction with awards category (Table 6). For example,

\footnotetext{
${ }^{2}$ Benefits are intended to provide employees and their families with a certainty. Benefits included two types of program: (1) employees protection program; health insurance, pension insurance, social insurance, disability insurance, life insurance and so on and (2) compensated absences: military service, vacation, sick leaves and so on. Privileges are connected to status and status features and included: free food or food at reduced prices, using of company car, free recreation, using of cell phone and so on (for more details see: Biljana Bogicevic, 268).
} 
the first item within this category of satisfaction ("When I work well, I get acknowledgment which I deserve") has $42.7 \%$ answers "disagree" and "strongly disagree" (the mean 2.84; SD 1.11). A relatively high percentage of examinees with neutral answers within this item $(25.41 \%)$ as well as within the fourth item $(29.73 \%)$ can be the consequence of the examinees' insufficient understanding of the award category. The second item within the category of teachers' satisfaction with awards ("Work $I$ do in the organization is not valued appropriately") has the mean of 3.31 (SD 1.12). Not a small number of examinees $(49.73 \%)$ have answered "agree" or "strongly agree" to the question in this item. A certain number of examinees (28.64\%) "disagree" or "strongly disagree" with the above mentioned statement, which indicates that there are teachers who think that their work is appropriately valued. The third item from this category ("Awards for employees in this organization are modest") shows that there are some examinees who consider work they do in the organization well valued (the second item) and they also consider awards for employees in concrete school modest. $70.81 \%$ of examinees "agree" or "strongly agree" with the statement included in the third item of the analyzed category. The consequence of this fact is the highest (within the analyzed category) mean of the third item (3.74; SD 1.00). The fourth item within this category of teachers' satisfaction ("My efforts in this organization are not awarded appropriately") has the mean of 3.41 (SD 1.04). Within this item, almost half of the examinees $(49.73 \%)$ "agree" or "strongly agree" with the statement included in the item. There is a considerable share $(29.73 \%)$ of examinees who have given a neutral answer. The fourth and the second items within that category of satisfaction are similar at first glance, so they resulted in similar answers of the examinees (in percentage and statistically). Namely, these are different items, where the second shows the attitude of the examinees in relation to the valuation of their work, while the fourth shows the attitude of examinees about the level of adequacy in rewarding their efforts at work.

Operational procedures reflect the level of formalization within an organization. In our research, this category of job satisfaction (Table 7) shows the level of teachers' satisfaction with the level of presence, implementation of different rules and procedures, paperwork and schools' "bureaucracy"; this, also, shows the degree to which teachers perceive their workload. The mean is above 3.00 for all four items within this category of satisfaction. The first item "Numerous rules and procedures in this organization contribute to difficulty achieving high-quality performance" had the mean of 3.09 (SD 1.14). Although $36.21 \%$ of examinees said "agree" of "strongly agree" related to this statement, a considerable percent (30.27\%) shows "neutral" attitude concerning this item. Examinees were given a similar number of neutral answers (31.35\%) related to the second item ("My efforts directed towards high-quality performance are rarely blocked by bureaucratic procedures"). With $40 \%$ of examinees who answered "agree" or "strongly agree", we have got the mean of 3.16 (SD 1.03) 
for that item. The third item ("I must do a lot at the work") reflects the way the employees perceive the work. The mean of 3.50 (SD 1.00) shows the majority $(57.29 \%)$ of examinees who "agree" or "strongly agree" with the statement on the item mentioned. $16.75 \%$ of examinees "disagree" or "strongly disagree" with this statement. The highest mean (3.91; SD 1.07) within this category of teachers' satisfaction was identified within the fourth item ("I am confronted with a lot of paperwork during my work"). $78.38 \%$ of examinees "agree" or "strongly agree" with the statement that there is a lot of "paperwork" in their work. That fact is not a surprise because school is considered as an organization with "professional" model of organizational structure which is characterized by a higher level of standardization and formalization (Mintzberg, 1992).

"Encouraging" results are identified within category "Teachers' satisfaction with colleagues" (Table 8). The first item within that category ("I love people with who I work") has mean 4.06 (SD 0.74) and it shows that the majority of examinees $(70.54 \%)$ loves their colleagues. High mean $(4.04$; SD 0.82$)$ is presented within the third item ("I feel good in the company of my colleagues") of that category of teacher satisfaction. The mean of the second item ("I must do more at the work because of incompetence of my colleagues") is 2.32 (SD 1.02) and it shows that teachers not only love their colleagues and their colleagues' company, but also the majority of examinees (63.79) consider their colleagues competent for the work they do. When it comes to competition among teachers, it is considered within the fourth item ("There is a lot of debates and rivalry among colleagues"). The great number of examinees $(42.16 \%)$ thinks that mentioned statement is true. Almost identical number of examinees disagreed with this statement $(28.11 \%)$ or had a neutral statement $(29.73 \%)$. That has resulted in the fourth item's mean 3.18 (SD 1.10).

The highest level of teachers' satisfaction is within category Teachers' satisfaction with the job itself (Table 9). The highest values of the mean and the lowest values of the standard deviation for all positively directed items (second, third and fourth item) are identified there, as well as almost the lowest mean for the first item which is negatively directed. The first item within this category of satisfaction ("I think sometimes that my work is meaningless") has the mean of 2.20 (SD 1.15) which shows that the majority of examinees (64.86\%) "strongly disagree" or "disagree" with the mentioned statement. A relatively modest number of examinees (15.67\%) "agree" or "strongly agree" with this statement. High values of the mean were gained within the second item ("I enjoy doing my work"), where the mean has been 4.29 (SD 0.73); the third item ("I am proud because of work I am doing ") 4.23 (SD 0.81) and the fourth item ("My work is pleasant") 4.03 (SD 0.93); these values have shown that teachers have been working in elementary schools in the Republic of Serbia love their job, enjoy it and are proud of it. This category of satisfaction also has the lowest percent of "neutral" answers within each item. 
The system of communicating (formal and informal) within organizations allows a transfer of information. This system quality can reflect on the teachers' satisfaction level. In that sense, the last category of teachers' satisfaction is about their satisfaction with communication within schools. The general teachers' attitude to their satisfaction with the system of communicating is analyzed in the first item ("There is good communication in this organization"). The greatest percent of examinees (56.75\%) "agree" or "strongly agree" with this statement. $23.78 \%$ of examinees have "neutral" attitude on that, while the rest of the examinees (18.91\%) "disagree" or "strongly disagree". The mean of this item is 3.44 (SD 1.02). The remaining three questions within this category of satisfaction are negatively directed and their values of mean are lower than 3.00. For example, the second item "This organization's aims are not totally clear to me" has the mean of 2.25 (SD 1.00) because the greatest number of examinees (63.78\%) disagree with the mentioned statement. The third item "I often have a feeling that I do not know what is happening in this organization" has the mean of 2.70 (SD 1.14). $45.95 \%$ of the total number of examinees "disagree" or "strongly disagrees with this statement, while not a great number of them $(25.95 \%)$ have a neutral opinion. The last item, "Employees often do not understand tasks in this organization" has the mean of 2.60 (SD 1.08). Almost half of the examinees $(49.73 \%)$ disagree with the statement within that item. Not a small number of examinees $(27.03 \%)$ show a neutral opinion.

The data presented in Tables 11 and 12 clearly show that teachers in elementary schools in the Republic of Serbia are dissatisfied with salaries (A), awards (E) and benefits (D). When it comes to the intensity of dissatisfaction, the next one is with operational procedures $(\mathrm{F})$ and with promotion opportunities (B). On the other hand, teachers are mostly satisfied with the work they do $(H)$, with their superiors $(C)$, with their colleagues $(G)$ and with system of communicating. It ensues that the main causes of dissatisfaction of teachers in elementary schools in the Republic of Serbia are external (teachers receive their salaries from the budget; awards and benefits are mostly caused by the disposal of material resources which school is getting from the state).On the other hand, the highest level of teachers' satisfaction is result of some "internal" and organizational caused factors from schools (for example, work which they are doing, relation between superiors and other colleagues, on one hand, and teachers, on the other hand, system of internal communication within school).

This leads to the conclusion that it is possible to influence the teachers' satisfaction level and, indirectly, improve their results, with the help of some interventions of the state which are directed to the improvement of the materialfinancial status of teachers in the Republic of Serbia. 


\section{Conclusion}

Certain levels of teachers' satisfaction or dissatisfaction, to some extent, can be reflected in individual results of an employee, as well as in total organizational performances. It means that dissatisfaction of teachers in elementary schools in the Republic of Serbia which has been identified within different categories of satisfaction has had a negative influence on teachers' individual results, level of their motivation and dedication at work, as well as on their pupils' success. The fact is that the mentioned dissatisfaction is the consequence of teachers' dissatisfaction with some categories which are caused externally and which are determined by some state decisions. By allocating greater amount of funds for salaries of employees in elementary schools as well as for work of schools, the state could not only increase levels of satisfaction of teachers in elementary schools, but also contribute to the promotion of the elementary education system in the Republic of Serbia.

Although the research findings have some limitations (primarily regarding the size and structure of the sample), it is expected that the theme and content of this paper could be an impetus for the future more comprehensive and more complete research dedicated to examining the degree of satisfaction of teachers in the Republic of Serbia.

\section{References}

Bogićević Milikić B. (2014) Menadžment ljudskih resursa, Beograd: Ekonomski fakultet u Beogradu

Bishay A. (1996) "Teacher motivation and job satisfaction: a study of employing the experience sampling method", Journal of Undergraduate Science, 3: 147-154.

Davis Keith, Newstrom John W. (1989) Human Behavior at Work - Organizational Behavior, New York: McGraw-Hill.

Dinham S., Scott C., (1998), "A three domain model of teacher and school executive satisfaction", Journal of Educational Administration, 36: 362-378.

Dinham S., Scott C., (2000), "Moving into the third outer domain of teacher satisfaction", Journal of Educational Administration, 38: 379-396.

DuBrin Andrew J. (1988)The Practice of Supervision, New Delhi: Universal Bookstall.

Evans L. (1998) Teacher Morale, Job Satisfaction and Motivation, London: Paul Chapman Publishing Limited.

Feldman D.C., Arnold H.J. (1983)Managing Individual and Group Behavior in Organizations,New York: McGraw-Hill.

Klassen R. M., Usher E. L., Bong M. (2010), "Teachers' collective efficacy, job satisfaction and job stress in cross-cultural context", The Journal of Experimental Education, 78: 464-486.

Kreitner R., Kinicki A. (1995)Organizational Behavior, USA: Richard D. Irwin, Inc. 
Locke E. A. (1976),,The Nature and Causes of Job-satisfaction“, preuzeto iz: Luthans F., (2008), Organizational Behavior, New York: McGraw Hill.

Mintzberg H. (1992) Structure in fives: Designing effective organizations, New Jersey: Prentice Hall.

Sharma R. D., Jyoty J. (2006), "Job satisfaction among school teachers", IIMB Management Review, 18 (4): 349-363.

Simić I.(2010) Osnovi organizacije, Niš: Ekonomski fakultet Univerziteta u Nišu.

Simić I., Stojković N. (2014) „Manager's role in raising the level of job satisfaction“, Facta Universitatis, Series: Economics and Organization, 11 (2): 163-174.

Spector P. E. (1985) "Measurement of human service staff satisfaction: Development of the job satisfaction survey", American Journal of Community Psychology, 13 (6), pp. 693-713.

Van den Berg (2002) “Teachers' meanings regarding educational practice", Review of Educational Research, 72: 577-625.

\section{ISTRAŽIVANJE ZADOVOLJSTVA NASTAVNIKA U OSNOVNIM ŠKOLAMA U REPUBLICI SRBIJI}

Apstrakt: Zadovoljstvo zaposlenih predstavlja jednu od često proučavanih podgrupa ljudskih stavova povezanih sa organizacionim ambijentom. Cilj autora ovog rada bio je da istraže različite kategorije zadovoljstva, odnosno nezadovoljstva nastavnika u osnovnim školama u Republici Srbiji, kao specifične kategorije zaposlenih. Rezultati sprovedenog istraživanja su pokazali da su nastavnici najnezadovoljniji zaradama, nagradama i beneficijama. Po intenzitetu nezadovoljstva sledi njihovo nezadovoljstvo operativnim procedurama. S druge strane, nastavnici su u najvećoj meri zadovoljni poslom koji obavljaju, svojim nadređenima, svojim kolegama i sistemom komuniciranja u okviru škole.

Ključne reči: zadovoljstvo, nastavnici, Republika Srbija 